\title{
On the mycelial growth of the lorel or false morel, Gyromitra esculenta (Pers.) Fr.
}

\author{
ILMA ROPONEN and MATTI KREULA
}

\begin{abstract}
ROPONEN, I. \& KREULA, M. 1978: On the mycelial growth of the lorel or false morel, Gyromitra esculenta (Pers.) Fr. - Karstenia 18 (suppl.).

The growth factors of lorel mycelia were investigated in solid and liquid media. The mycelial strains used in the experiments were isolated by germinating spores of lorels in Petri dishes on nutrient agar. The strains isolated were stored in the cold in test tubes as pure cultures, and propagated vegetatively by inoculation. The results showed that the production of spawn is possible in axenic substrates. This method of cultivation needs a high degree of sanitation. Spawn growth is at a maximum after 3-4 weeks, when the substrate is fully covered with the mycelium.

The $\mathrm{pH}$ range 4-7 was observed to be fabourable for the growth of the mycelia tested. The mycella grew vigorously when formic acid was added to a concentration of $0.01-0.1$ per cent in the substrate, but growth was inhibited when the concentration was 0.2 per cen. or cent in the substrate, but growth was inhibited when the concentration was 0.2 per cen.
more. The effect of temperature on mycelial growth was tested at $+5^{\circ}, 10^{\circ}, 15^{\circ}, 20^{\circ}$ and more. The effect of temperature on mycelial growth was tested at $+5^{\circ}, 10^{\circ}, 15^{\circ}, 20^{\circ}$ and
$30^{\circ} \mathrm{C}$; optimum growth was obtained at $10-25^{\circ} \mathrm{C}$. The mycel ia were very sensitive to elevated $\mathrm{CO}_{2}$ concentrations, and effective aeration and shaking were needed for growth in liquid substrate.

Waste materials from the prepared pulp industry containing hemicellulose and Iignin appear to be suitable for the cultivation of lorel mycelia after the addition of a small amount of urea.
\end{abstract}

1. Roponen \& M. Kreula, Laboratory of the Foundation for Chemical Research, Biochemical Research Institute, Kalevankatu 56, SF-00180 Helsinki 18, Finland.

\section{Introduction}

The composition of mushrooms and the factors influencing their growth have been studied at the Biochemical Institute during the last few years. The cultivation of lorels (Gyromitra esculenta) has been very difficult. Some information about G.esculenta and factors that have an effect on its growth is presented here.

\section{Ocourrence, yield and use of the lorel}

G. esculenta, like Morchelza, belongs to the sub-class of Discomycetes and to the group of Pezizales.

The colour of the cap of the lorel varies from yellowish-brown to dark-red-brown. It is densely folded and its brim is arched inwards. The layer producing spores is on the surface of the dried cap as a white powder. Harmaja (1969 a, b, 1973 a, b) has studied the systematics of Gyromitra Fr.

The lorels appear early in the spring after the snow has melted. In southern Finland the fruit -bodies of the lorel appear as early as at the end of March, and in Lapland they can be found as late as in July. The species is common over the whole country, particularly on pine-growing moors. They are usually found in places where the surface layer of the soil is broken, that is, beside ditches, roads, patways and gravel-pits, and in forest-fire and log-felling areas where the mossy cover is thin or totally lacking, and in former woodpile and barking stands (Rauta- vaara 1947, Korhonen 1973). In Finland, studies on the effects of the breaking of the soil surface and the removal of peat on the growth of the lorel (Jalkanen 1975) as well as other pssobilities for its cultivation (Suhonen 1974) are in progress.

Another variety of Gyromitra, G. gigas, which is larger and lighter in colour than the ordinary lorel, is met to some extent in groves of southern and central Finland.

In Finland the lorel is one of the 30 commercial mushrooms (Pohjola et al. 1975) picked by trained collectors. The yield varies considerably in different years. As an example of the variation in yield Fig. I shows the quantities of lorels received yearly in 1972-76 (total 114 tons) by Valio Finnish Cooperative Dairies' Association for marketing.

These quantities do not comprise the whole yield of lorels collected in Finland during the above years, but they illustrate the variations in the yield in different years.

Fresh lorels are poisonous. Pyysalo (1975) has studied by gas chromatography-mass spectrometry the contents of toxins in lorels, i.e. gyromitrin and its homologues, and their removal from the mushrooms. In our laboratory we have also studied the toxic affects of gyromitrin in animal experiments. A careful 10 minutes' heating and rinsing or long-term drying removes the toxin, and the mushrooms can then be used for food. These results show that the old methods 
found by experience for destroying the toxin and making the lorel edible are sound. Due to their good flavour the lorels have always been popular.

Fig. 1. The quantities of Gyromitra esculenta delivered to the Valio Finnish Cooperative Dairies' Association in 1972-76.

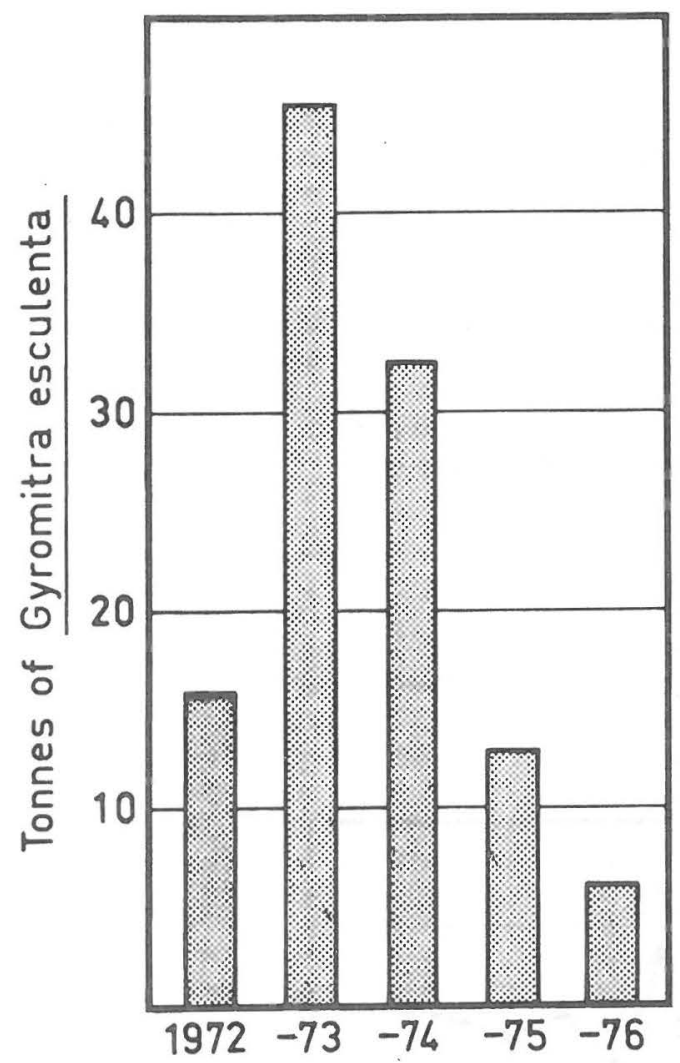

Methods for growing mycelia

It has not yet been possible to cultivate the sporophores of the lorel (G. esculenta) and of its relative Morchella under controlled conditions. However, much experience has been obtained in the cultivation of the mycelium of Morchelza (D'Yvoire 1889, Heim 1936, Brock 1951, Gilbert 1960, Litchfield et al. 1963, Makinen 1976), whereas only little is known about the factors effecting the mycelial growth of $G$. esculenta (Raudaskoski et al. 1976, 1977).

Solid (Sinden 1937) and liquid (Laniece 1966) substrates have been used for the production of mushroom mycelia. In the method of Sinden for Agaricus species, cooked grain to which calcium sulfate had been added was used. The substrate was inoculated with a pure culture of the mycelium and the culture flasks were shaken after inoculation and thereafter once a week. Under favourable conditions the mycelia completely covered the substrate in 3-4 weeks. In the Philippines the mycelium of Volvarielza has been grown in moistened chopped straw (Ho 1972).

In the plant department of the Biochemical Research Institute the cultivation of certain native edible mushrooms, such as Pleurotus ostreatus, Flammulina velutipes, Kuechneromyces mutabilis and Naematoloma capnoides has been studied. This work has included also a study of mycelial growth of the lorel (Roponen 1975). In the present study the suitability of certain wood waste materials as substrate for the mycelium of the lorel was tested. The effect of acidity, temperature, light and aeration on the mycelial growth was also examined.

\section{Materials and methods}

The mycelial strains of the lorel used in the experiments, $\mathrm{Kl} \times 3$ and $\mathrm{K} 9$, were isolated from single sporophores obtained from southern and central Finland by growing their spores on nutrient agar in Petri dishes. The isolated strains were stored as slant surface cultures in test tubes on a $2 \%$ malt-agar or modified Hagem-agar in a refrigerator $\left(+4^{\circ} \mathrm{C}\right)$. The vegetative inoculation of the mycelia was performed aseptically. Strains as vigorous as possible were selected from the mycelial strains cultivated from spores (Zamenhof et al. 1967, Wills 1968, Peng 1972).

The tests were conducted in test tubes, Petri dishes and flasks. The liquid media used contained $1 \%$ hemicellulose and Ca-lignosulfonate (both dried waste wood materials). The solid substrates, in flasks, were as follows: fresh and old (kept for a year outdoors) birch and pine bark residue; undecomposed and decomposed pine litter; sawdust-wheat bran (3:1). Urea, 75-320 $\mathrm{mg}$ per litre distilled water, was added as the nitrogen source, and the control media contained no added urea.

The substrates were autoclaved at $120^{\circ} \mathrm{C}$ for $30 \mathrm{~min}$. The $\mathrm{pH}$ was adjusted with $\mathrm{KOH}$ or $\mathrm{HCl}$ before sterilization. After inoculation the cultures were incubated for 4 weeks. Nitrogen contents were determined by Kjeldahl analyses. Formic acid (98-100\% pro analysi) was obtained from Merck.

The incubation of cultures was carried out at the constantly regulated temperatures of +5 to $30^{\circ}$ $C$ or in a greenhouse in which the air temperature was $18-24^{\circ} \mathrm{C}$ during the day and 8-14\% $\mathrm{C}$ at night. In addition to daylight the cultures were given artifical light (Philips HDK 251, $400 \mathrm{~W}$ ) for $16 \mathrm{~h}$ per day (from 5 a.m. to 9 p.m.) in winter.

The relative rate of mycelial growth was obtained from the maximal rate of extension of the colony diameter in $\mathrm{mm}$ or from the weight of mycelium dry matter in $\mathrm{mg}$ on a given medium. On solid substrates of bark residue and litter the estimation of growth was made by naked eye and under a Reichert microscope. 
Preliminary tests were performed in aerated liquid culture in flasks and in aerated plastic film tubes. The poor growth observed in these tests shows that further detailed studies are necessary.

\section{Results and discussion}

Effect of acidity on the growth of mycelia

Fig. 2 shows that mycelial strain Klx3 of the lorel grew well at $\mathrm{pH}$ 4-7. The most suitable acidity for most mushrooms is pH 5-7 (Smith et al. 1975).

Effect of temperature on mycelial growth

Fig. 3 shows the results of a series of tests according to which mycelial strain $\mathrm{Kl} \times 3$ grew well at temperatures from $+10^{\circ}$ to $+25^{\circ} \mathrm{C}$. At $+5^{\circ} \mathrm{C}$ the growth was about half of that at the optimum temperature, while at $+30^{\circ} \mathrm{C}$ it was particularly poor. Also in the experiments of Treschow (1944) the growth of white mycelial strains increased fairly evenly up to $+24^{\circ}$ $C$, after which it decreased shaprly.

Effect of formic acid on mycelial growth

When 0.01-0.1\% formic acid was added to the substrate the growth of mycelia increased considerably. Addition of $0.2 \%$ formic acid to the substrate prevented entirely the growth of mycelial strain $\mathrm{Kg}$ (Table 1). The formic acid test was performed since it has been observed that in its natural habitat the lorel grows close to ant -paths. The object was to test whether the formic acid excreted by ants has an effect on the growth of the mushrooms, or whether the association is due to spores being transported by ants. The test showed that formic acid promotes mycelial growth. Certain scientists have tried to elucidate the beneficial effect of ants on the growth of mushrooms (Weber 1966, Martin 1970, Schmid 1971).

Effect of light on mycelial growth

The action of light on the growth of mushrooms varies. Champignons grow and develop fruit-bodies in the dark. The studies have shown that some species of Basidiomycetes need light for fruiting initiation, for instance pleurotus strains. When the mycelia of the lorel were grown in light in the greenhouse their growth became slower and the white mycelia began to turn brown and form dense patches. Raudaskoski et al. (1976) have obtained similar results with the mycelia of $G$. esculenta and Mäkinen (1976) with the mycelia of Morchezza esculenta.

Fig. 2. The effect of $\mathrm{pH}$ on the growth of the myceiium

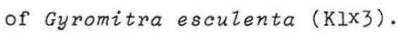

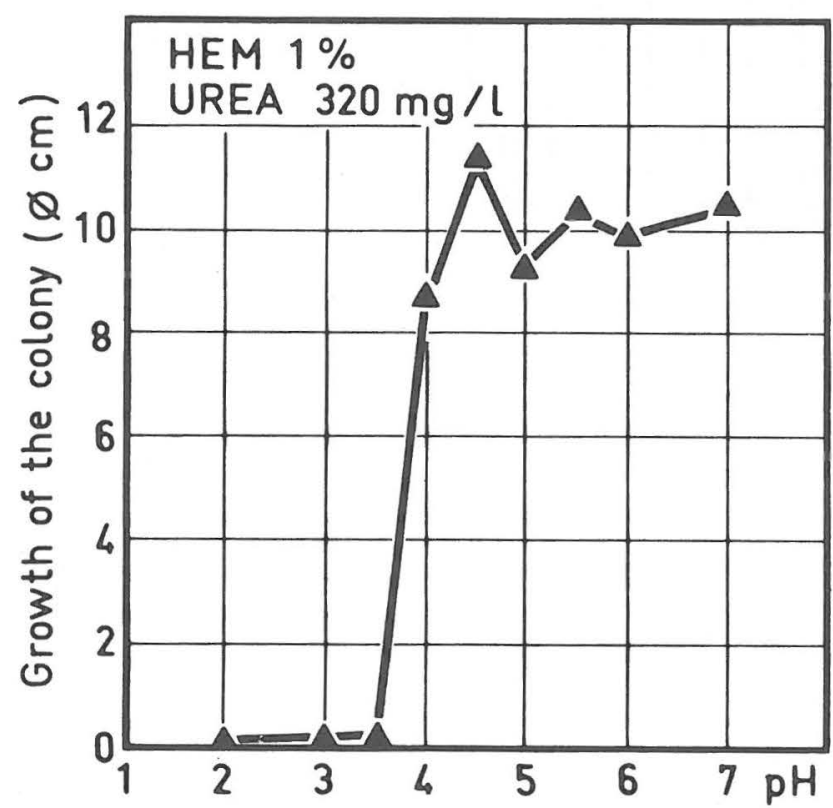


Fig. 3. The effect of temperature on the growth of the mycelium of Gyromitra esculenta (KIX3).

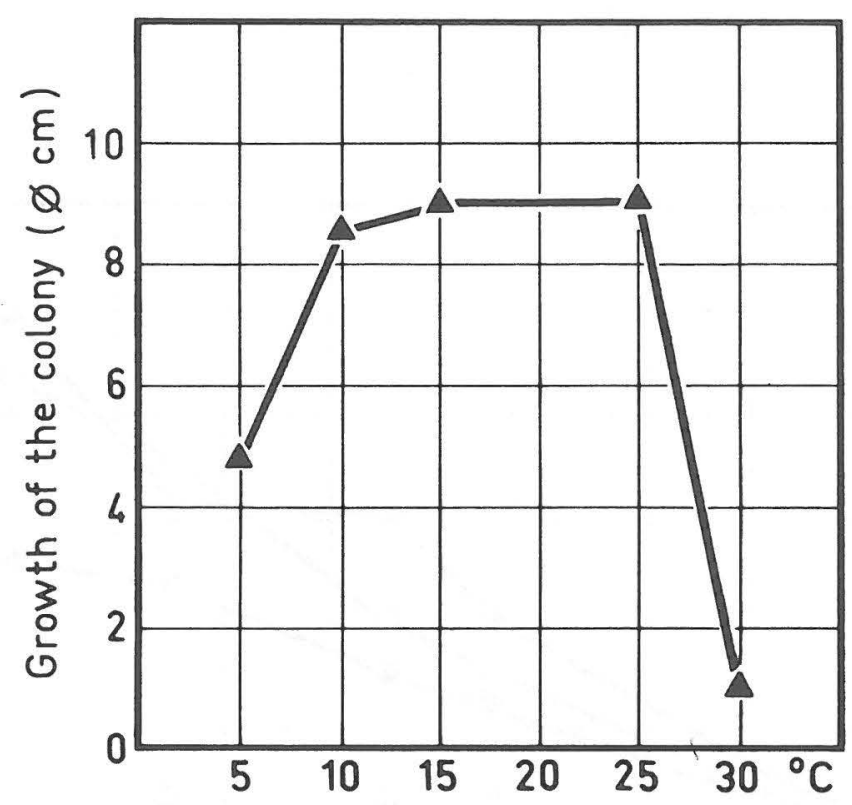

Table 1. The effect of formic acid on the mycelial growth of the lorel (Strain K9) on a $1 \%$ hemicellulose and $0.032 \%$ urea substrate. The growth period was four weeks. Each test was made in triplicate. The initial acidity was adjusted with $\mathrm{KOH}$ to $\mathrm{pH} 4.2$.

\begin{tabular}{|c|c|c|c|c|c|}
\hline $\mathrm{HCOOH}, \mathrm{ml} / \mathrm{I}$ in substrate & $\begin{array}{l}\text { Fresh weight of } \\
\text { mycelium, mg }\end{array}$ & $\begin{array}{l}\text { Dry weight of } \\
\text { mycelium, mg }\end{array}$ & $\begin{array}{l}\text { Dry matter of } \\
\text { mycelium, } \%\end{array}$ & $\begin{array}{l}\text { N content of } \\
\text { mycelium, } \\
\text { of dry wt. }\end{array}$ & $\begin{array}{l}\text { Total N of } \\
\text { mycelium, mg }\end{array}$ \\
\hline 0 & 684 & 135 & 20 & 4.7 & 6.3 \\
0.1 & 765 & 237 & 31 & 4.4 & 8.6 \\
0.5 & 1212 & 224 & 18 & 4.4 & 10.0 \\
1.0 & 3188 & 197 & 6 & 4.7 & 11.2 \\
2.0 & 0 & 0 & 0 & 0 & 0 \\
5.0 & 0 & 0 & 0 & 0 & 0 \\
\hline
\end{tabular}

Mycelial growth of the lorel in waste materials from the cellulose industry

Hemicellulose and lignosulfonate are waste materials of cellulose production and could be used as substrates for mushrooms, with urea as the source of nitrogen. In our experiments the mycelium of the lorel did not frow on media containing solely hemicellulose or calcium lignosulfonate in distilled water. In contrast, on media containing hemicellulose and urea, or hemicellulose, urea and lignosulfonate, the mycelium grew well; in fact better than on a $1 \%$ malt extract (Fig. 4).
In wheat grain moistened with a hemicellulose -urea solution and on sawdust-wheat bran substrate mycelial strain Klx3 grew well. In a hemicellulose -urea liquid culture the mycelium grew only on the surface of the liquid. The liquid layer had to be shallow (below $5 \mathrm{~cm}$ ).

In fresh waste bark from birch and pine moistened with a hemicellulose-urea solution and in fresh pine litter the mycelia of the lorel did not grow at all, or at most very poorly. The mycelia grew only on decomposed waste material. 
Fig. 4. The growth $(\varnothing \mathrm{cm})$ of the mycelium of Gyromitra esculenta (strain K9) in Petri dishes in pure liquid cultures. The substrates contained: (1) 1\% hemicellulose, 1\% calcium lignosulfonate and $0.032 \%$ urea, (2) $1 \%$ hemicellulose and $0.032 \%$ urea, (3) $1 \%$ malt extract, (4) $1 \%$ hemicellulose and (5) $1 \%$ calcium lignosulfonate.

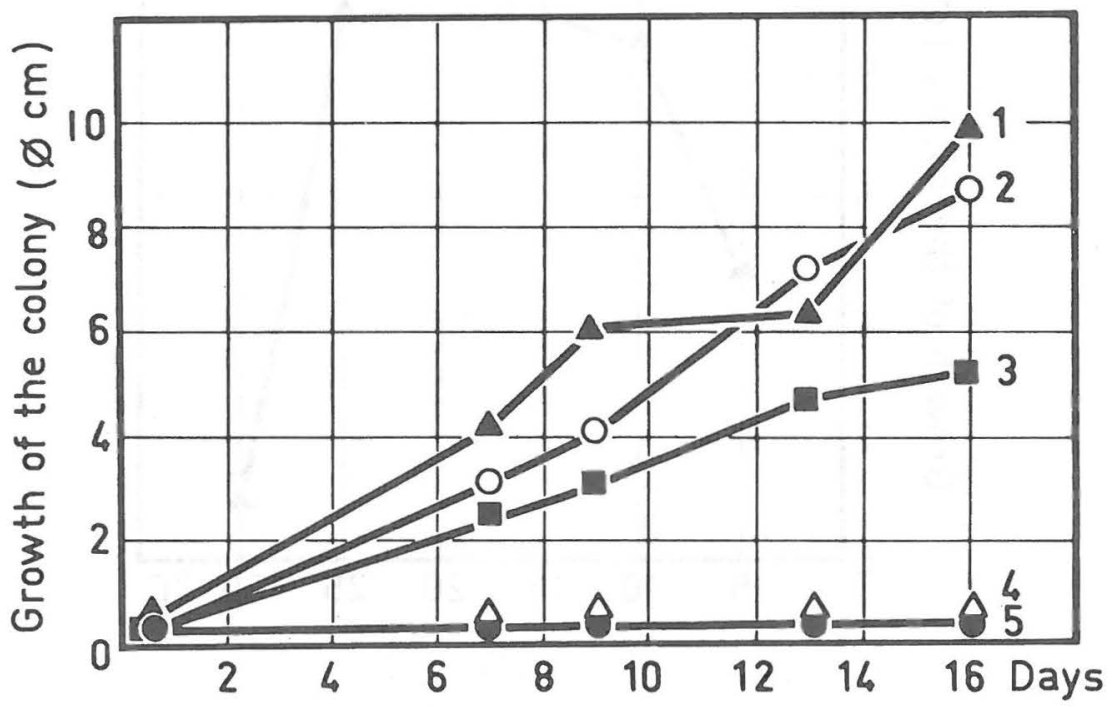

\section{References}

Brock, T.C. 1951: Studies of the nutrition of Morchella esculenta Fr. - Mycologia 43: 402-422.

Gilbert, F.A. 1960: The submerged culture of Morchella. - Mycologia 52: 201-209.

Harmaja, H. 1969a: A wider and more natural concept of the genus Gyromitra Fr. - Karstenia 9: 9-12.

-"- 1969b: A neglected species, Gyromitra ambigua (Karst.) Harmaja, n. comb., and G. infula s.str. in Fennoskandia. - Karstenia 9: 13-19.

-" 1973a: Piispanhiippa käsittăkin kaksi eri lajia, joista toinen ehkä myrkyllinen. - Sienilehti 25 (3): 10-12.

-"- 1973b: Amendments of the limits of the genera Gyromitra and Pseudorhizina, with the description of a new species, Gyromitra montana. Karstenia 13: 48-58.

Heim, R. 1936: La culture des morilles. - Rev. Mycol. 1 (suppl. 1): 10-11, (suppl.2): 19-25.

Ho, M.-S. 1972: Straw mushroom cultivation in plastic houses. - Mushroom science 8: 257-263.

Jalkanen, E. 1975: Luonnossa tapahtuvien korvasienen viljelykokeiden ongelmia. - Sienitalousseminaari 7-8.4. 1975, Jyväskylän yliopisto, Biologian laitos, Tiedonantoja 1: 13-14. Jyväskylä.

Korhonen, M. 1973: 100 sientä. - 168 pp. Helsinki.
Laniece, A. 1966: Production and use of liquid mushroom spawn. U.S. Patent Office 3,286,399.

Litchfield, J.H., Overbeck, R.C. \& Davidson, R.S. 1963: Factors affecting the growth of morel mushroom mycelium in submerged culture. - Agric. Food Chem. 11: 158-162.

Martin, M.M. 1970: The biochemical basis of the fungus attine ant symbiosis. - Science 169: 16-25.

Mäkinen, Y. 1976: Huhtasienen viljelykokeista. (Cultivation experiments with morel.) - Luonnontutkija $80: 33-40$.

Peng, J.-T. \& Wu, L.-C. 1972: Variations in the cultivated mushrooms. - Mushroom Science 8: 103-113.

Pohjola, K., Hintikka, V., Măkinen, Y. \& Layout Christiansson, I. 1975: Metsalsienineuvojen opas. - Ammattikasvatushallitus, Metsäopetuksen osasto. $75 \mathrm{pp}$.

Pyysalo, H. 1975a: Gyromitriini korvasieniruoissa. Sienilehti 27 (2): 39.

-" - 1975b: Studies on the volatile compounds in mushrooms. - Dr. Ph. Thesis 139 pp. - Technical Research Centre of Finland, Helsinki.

Raudaskoski, M., Pohjola, K. \& Saarvanto, I. 1976: Effect of temperature and light on the mycelial growth of Gyromitra esculenta in pure culture. - Karstenia 16: 1-5. 
-" 1977: Lämpütilan ja valon vaikutus korvasienen rihmaston kasvuun puhdasviljelmässă. - Sienilehti $29: 15$.

Rautavaara, T. 1947: Suomen sienisato. - 534 pp. Porvoo. Roponen, I. 1975: Korvasienten kasvatuksesta laboratorio-olosuhteissa. - Sienitalousseminaari 7-8.4. 1975, Jyvăskylän yliopisto, Biologian laitos, Tiedonantoja 1: 12-13. Jyväskylä.

Schmid, R. 1971: Biochemische Grundlage der Symbiose zwischen Aneisen und Pilzen. - Naturw. Rdsch. 24: $482-485$.

Sinden, J.W. 1936: U.S. Patent 2,044,861.

Smith, J.E. \& Eerg, D.R. 1975: The filamentous fungi.I. Industrial Mycology. - $340 \mathrm{pp}$. London.

Suhonen, I. 1974: Selvitys syötäviin sieniin kohdis- tuvasta tutkimuksesta Suomessa. - Kuopio, Kehitysaluerahasto oy.

Treschow, C. 1944: Nutrition of cultivated mushroom. Dansk Bot. Arkiv 11: 1-180.

Weber, N.A. 1966: Fungus-growing ants. - Science 153: $587-604$

Wills, C. 1968: Yeast partial dominance: effect of environment and background genotype. - Science 160: 549-550.

D'Yvoire, B. 1889: La morille. Procédé de culture potagére applicable à tous les jardins. - Bull. Soc. d'Acclimation 36: 18-26.

Zamenhof, S. \& Eichorn, H.H. 1967: Study of microbial evolution through loss of biosynthetic functions: Establishment of "defective" mutants. - Nature (London) 216: 456-458. 